\title{
EFFECT OF ORGANIC FERTILIZER SOURCE AND FOLIAR SPRAY WITH SOME MICROELEMENTS ON GROWTH, YIELD, FRUIT QUALITY AND STORABILITY OF STRAWBERRY UNDER SANDY SOIL CONDITIONS
}

\author{
Manal A. Mandour ${ }^{*}$ and Inas A. Bardisi ${ }^{2}$ \\ 1. Central Lab. Org. Agric., Agric. Res. Cent., Giza, Egypt \\ 2. Hort. Dept., Fac. Agric., Zagazig Univ., Egypt
}

\section{Received: 05/11/2019; Accepted: 05/01/2019}

\begin{abstract}
A filed experiment was carried out during the two successive winter seasons of 2017/2018 and 2018/2019 at the Experimental Farm of El-Kassasein, Hort. Res. Station, Ismailia Governorate, Egypt, to investigate the effect of different organic manure sources, i.e. chicken manure (3.75 ton/fad.) vermicompost (4.44 ton/fad.) and compost (7.50 ton/fad.) (equal $120 \mathrm{~kg} \mathrm{~N} / \mathrm{fad}$., of each), and foliar spray with some microelements ( $\mathrm{B}$ at $25 \mathrm{ppm}, \mathrm{Zn}$ at $100 \mathrm{ppm}$ and $\mathrm{Fe}$ at $200 \mathrm{ppm}$ ) on vegetative growth, yield, fruit quality and storability of strawberry under sandy soil conditions. Fertilizing strawberry plants grown in sandy soil with 4.44 ton vermicompost /fad increased foliage dry weight, average fruit weight, yield/plant, early yield and total yield/fad, fruit firmness, TSS and Vit. C and gave the lowest values of deformed fruits (\%) and fruit weight loss (\%) as well as decay (\%) during cold storage periods. Spraying with $\mathrm{Fe}$ at $200 \mathrm{ppm}$ increased foliage dry weight, average fruit weight, yield/plant, early yield and total yield/fad. Spraying with B at $25 \mathrm{ppm}$ increased fruit firmness, TSS and Vit. C, whereas spraying with Zn at $100 \mathrm{ppm}$ gave the lowest values of deformed fruits (\%) and fruit weight loss as well as decay (\%) during cold storage periods The interaction between fertilizing with vermicompost at 4.44 ton/fad., and spraying with $\mathrm{Fe}$ at $200 \mathrm{ppm}$, significantly increased foliage dry weight, average fruit weight, yield/plant, early yield and total yield/fad., whereas the interaction between fertilizing with vermicompost at 4.44 ton/fad., and spraying with $\mathrm{Zn}$ at 100 ppm gave the lowest value for each of fruit weight loss (\%) and fruit decay (\%) during cold storage periods. The interaction between fertilizing with vermicompost at 4.44 ton/fad., and spraying with $\mathrm{B}$ at 25 at ppm increased fruit firmness, TSS and Vit. C in fruits and moreover it gave the lowest value of deformed fruits (\%).
\end{abstract}

Key words: Strawberry, organic manure, vermicompost, compost, growth, yield, weight loss and decay.

\section{INTRODUCTION}

Strawberry (Fragaria $x$ ananassa Duch.) is one of the most popular vegetable crops. In Egypt, it occupies an important position among the exportable vegetable crops due to its multifarious use as local fresh consumption, food processing and exportation. The crop is commonly grown in sandy soils for getting early yields and good fruit quality. Sandy soils have their own problems as single grain structure, susceptibility to erosion, and low levels of

\footnotetext{
*Corresponding author: Tel. : +201002920456
}

E-mail address: manalmandour1968@gmail.com nutrients and organic matter as well as microorganisms (Nour, 1999). Owing to their poverty in nutrients and organic matter, fertilizer requirements of strawberry plants grown in such soils, are quite high. The excessive use of inorganic fertilizers might cause ground water contamination and environmental hazards, in addition to their high costs (Lee, 1992). Thus substitution of inorganic fertilizers with organic sources is needed.

Vermicomposts are finely-divided mature peat-like materials with a high porosity, aeration, 
drainage and water-holding capacity and microbial activity which are stabilized by interactions between earthworms and microorganisms in a non-thermophilic process (Edwards and Burrows, 1988). Vermicompost application at 10 ton/ha significantly increased leaf area, plant shoot biomass, number of flowers, number of runners and marketable fruit weight of strawberry (Arancon et al., 2004). Vermicompost at 7.5 ton/ha. increased total fruit yield, firmness, total soluble solids and ascorbic acid content of strawberry (Rajbir et al., 2008).

Zinc is effective in plant nutrition for the synthesis of plant hormones and balancing intake of $\mathrm{P}$ and $\mathrm{K}$ inside the plant cells. Boron is essential for plant growth, new cell division in meristematic tissue, translocation of sugar, starch, nitrogen, phosphorus, certain hormones, synthesis of amino acids and protein, regulations of carbohydrate metabolism, development of phloem etc. Iron act as catalyst in synthesis of chlorophyll molecule and helps on the absorption of other elements. It is a key element in various redox reactions of respiration, photosynthesis and reduction of nitrates and sulphates (Wallihan et al., 1958; Zende 1996).

Boron has an effect on cell wall structure, cell elongation (pollen tube) and root growth (Barker and Pilbeam, 2006). Zinc reduces pollen tube growth through functioning tryptophan as an auxin precursor biosynthesis (Chaplin and Westwood, 1980). Boron deficiency and poor pollination cause deformed berries. Micronutrients deficiencies such as boron may cause pollination problems.

Ekka et al. (2018) revealed that spraying with $\mathrm{Fe}$ at $0.4 \%$ recorded maximum values of plant height, number of leaves/plant, number of flowers per plant, number of fruits per plant, fruit yield per plant, TSS, total sugars, ascorbic acid and benefit cost ratio of strawberry cv. Chandler, whereas spraying with $\mathrm{Zn}$ at $0.2 \%$ recorded maximum values of fruit weight, fruit diameter, fruit length and specific gravity.

Therefore, the aim of this work was to obtained high yield and good quality of strawberry plants by using organic manure and foliar spray with microelements under sandy soil conditions.

\section{MATERIALS AND METHODS}

A filed experiment was carried out during the two successive winter seasons of 2017/2018 and 2018/2019 at the Experimental Farm of ElKassasein, Hort. Res. Station, Ismailia Governorate, Egypt, to investigate the effect of organic manure sources (chicken manure, vermicompost and compost) and foliar spray with some microelements $(\mathrm{B}, \mathrm{Zn}$ and $\mathrm{Fe})$ on vegetative growth, yield, fruit quality and storability of strawberry under sandy soil conditions. The soil was sandy in texture 0.08 and $0.09 \%$ organic matter, $7.92 \mathrm{pH}, 1.04$ $\mathrm{mmhos} / \mathrm{cm} \mathrm{EC}$.

Frigo transplants of strawberry (Festival cultivar) were transplanted on $25^{\text {th }}$ and $27^{\text {th }}$ September during the $1^{\text {st }}$ and $2^{\text {nd }}$ seasons, respectively. The experimental unit area was $12.6 \mathrm{~m}^{2}$, It contains three dripper lines of $6 \mathrm{~m}$ length and 0.7 distance between each two dripper lines. The distance between strawberry transplants was $25 \mathrm{~cm}$.

This experiment included 12 treatments, which were the combinations between three sources of organic manure, i.e., chicken manure $(3.2 \% \mathrm{~N})$ at 3.75 ton/fad., vermicompost $(2.7 \%$ $\mathrm{N})$ at 4.44 ton/fad., and compost $(1.6 \% \mathrm{~N})$ at $7.50 \mathrm{ton} / \mathrm{fad}$. (equal $120 \mathrm{~kg} \mathrm{~N} / \mathrm{fad}$.) and three microelements, i.e., $\mathrm{B}$ at $25 \mathrm{ppm}, \mathrm{Zn}$ at $100 \mathrm{ppm}$ and $\mathrm{Fe}$ at $200 \mathrm{ppm}$ in the form of $\mathrm{H}_{2} \mathrm{BO}_{3}, \mathrm{ZnSO}_{4}$ and $\mathrm{FeSO}_{4}$, respectively, beside unsprayed plants. These treatments were arranged in a split plot design with three replicates. Organic manure sources were randomly arranged in the main plots, while foliar application with microelements were randomly arranged in the sub plots. Organic manure sources were placed pre transplanting and microelements $(\mathrm{B}, \mathrm{Zn}$ and $\mathrm{Fe}$ ) were sprayed four times at $70,85,100$ and 115 days after transplanting. Untreated plants were left as a control treatment and sprayed with tap water. The agricultural practices concerning cultivation, irrigation, fertilization and insect control were conducted according to Ministry of Agriculture recommendation.

\section{Data Recorded}

\section{Plant growth}

Random samples each of five plants from each plot were randomly taken at 120 days after 
transplanting in the two growing seasons for measuring the vegetative growth, i.e., plant height $(\mathrm{cm})$, number of leaves/plant and shoot dry weight/plant (g) which measured using dried fresh shoot/plant at $70^{\circ} \mathrm{C}$ till constant weight.

\section{$N$, $P$ and $K$ contents in shoots}

Nitrogen, phosphorus and potassium percentages in shoots (leaves and branches) were determined in dry weight at 120 days after transplanting in the $2^{\text {nd }}$ season according to AOAC (2005), and total protein percentage in dry shoots were determined by multiplying nitrogen content by 6.25 .

\section{Yield and its components}

The early yield was determined as weights of all harvested fruits from each plot during February and March months, and then early yield per fad., was calculated. Total yield was recorded from each plot as weights of all harvested fruits during the season up to mid of May, then, yield per plant (g) and total yield per fad. (ton) were calculated, also average fruit weight as well as deformed fruits percent were determined. (fad. $=4200 \mathrm{~m}^{2}=0.42$ ha.)

\section{Fe and $B$ contents in fruits}

Iron and boron contents (ppm) in the fruits at harvest time were determined by atomic absorption spectrophotometer as described by Evenhuis and De Waard (1980).

\section{Fruit quality at harvest}

Fruit quality was measured in the mid of the harvesting season as follows: Firmness was determined by using a Chattilon pressure meter equipped with a plunger (N4, USA) a needle $3 \mathrm{~mm}$ diameter. Total soluble solids contents (TSS) as brix : Samples of ten ripe fruits were chosen randomly from each experimental plot at full ripe stage to measure the percentage of total soluble solids content using the hand refractometer. Samples of $100 \mathrm{~g}$ fruits from each experimental plot at full ripe stage were randomly chosen to determine titratable acidity of juice by titration with $0.1 \mathrm{NaOH}$ solution, according to the method described in AOAC (2005). Ascorbic acid content (Vit. C), was determined in juice as the method mentioned in AOAC (2005).

\section{Storability}

At ripe stage, $500 \mathrm{~g}$ of strawberries fruits (uniform size and color) of each experimental unit were freshly harvested, surface-dried using blotting paper, divided into three lots (different cold storage periods, 5, 10, and 15 days) were stored at zero ${ }^{\circ} \mathrm{C} \pm 1{ }^{\circ} \mathrm{C}$ and $90-95 \%$ relative humidity, to determine the following data:

\section{Weight loss (\%)}

Weight loss percentage was measured at 5 , 10 and 15 days from cold storage. Fruits of each treatment were weighed after 5 days by intervals, then weight loss percentage was calculated. The weight was measured by Digital Electrical Balance at zero day and was taken as reference weight then it was calculated by using the following equation:

Weight loss $(\%)=$ Initial weight - Weight of fruits at different sampling dates $\div$ Initial weight of fruits $\times 100$

\section{Fruit decay (\%)}

Percentage of fruit decay was calculated after 5, 10 and 15 days from cold storage.

\section{Statistical Analysis}

Recorded data were subjected to the statistical analysis of variance according to Snedecor and Cochran (1980) and means separation was done according to least significant difference (LSD) at 0.05 levels of probability.

\section{RESULTS AND DISCUSSION}

\section{Plant Growth}

Fertilizing strawberry plants grown in sandy soil with 4.44 ton vermicompost/fad., recorded the tallest plants and gave the highest number of leaves/ plant and foliage dry weight/ plant at 120 days after transplanting followed by chicken manure at 3.75 ton/fad., (Table 1). These results agree with those reported by Arancon et al. (2004).

Foliar spray with B at $25 \mathrm{ppm}, \mathrm{Zn}$ at 100 ppm and $\mathrm{Fe}$ at $200 \mathrm{ppm}$ increased plant height, number of leaves/plant and foliage dry weight/ plant compared to control (sprayed with tap water). Spraying with Fe at 200 ppm significantly 
Table 1. Effect of organic manure and foliar spray with some microelements on growth parameters of strawberry plants at 120 days after transplanting during 2017/2018 and 2018/2019 seasons

\begin{tabular}{lcccccc}
\hline Treatment & \multicolumn{2}{c}{ Plant height $(\mathbf{c m})$} & \multicolumn{2}{c}{ Leaf number/plant } & \multicolumn{2}{c}{ Foliage dry weight (g) } \\
\cline { 2 - 7 } & $\begin{array}{c}\mathbf{1}^{\text {st }} \\
\text { season }\end{array}$ & $\begin{array}{c}\mathbf{2}^{\text {nd }} \\
\text { season }\end{array}$ & $\begin{array}{c}\mathbf{1}^{\text {st }} \\
\text { season }\end{array}$ & $\begin{array}{c}\mathbf{2}^{\text {nd }} \\
\text { season }\end{array}$ & $\begin{array}{c}\mathbf{1}^{\text {st }} \\
\text { season }\end{array}$ & $\begin{array}{c}\mathbf{2}^{\text {nd }} \\
\text { season }\end{array}$ \\
\hline Chicken manure & 15.78 & 14.95 & 25.83 & 26.53 & 31.55 & 32.53 \\
Vermicompost & 16.67 & 16.55 & 27.70 & 28.27 & 34.67 & 35.03 \\
Compost & 14.20 & 12.99 & 23.58 & 23.89 & 26.73 & 27.29 \\
LSD at 0.05 level & $\mathbf{0 . 9 9}$ & $\mathbf{0 . 7 0}$ & $\mathbf{0 . 4 9}$ & $\mathbf{1 . 3 0}$ & $\mathbf{1 . 0 5}$ & $\mathbf{1 . 0 2}$ \\
& & & Microelement (ppm) & & \\
Control & 13.10 & 12.11 & 23.32 & 23.82 & 20.94 & 20.83 \\
B at 25 & 15.11 & 14.68 & 26.27 & 26.62 & 32.00 & 32.66 \\
Zn at 100 & 16.50 & 15.49 & 26.05 & 26.44 & 34.03 & 35.00 \\
Fe at 200 & 17.49 & 17.05 & 27.16 & 28.05 & 36.98 & 37.99 \\
LSD ( 0.05) ) & $\mathbf{0 . 8 6}$ & $\mathbf{0 . 6 1}$ & $\mathbf{0 . 4 2}$ & $\mathbf{1 . 1 4}$ & $\mathbf{0 . 9 1}$ & $\mathbf{0 . 8 9}$ \\
\hline Q & & &
\end{tabular}

Quantity of chicken manure, vermicompost and compost were about 3.75, 4.44 and 7.50 ton/fad.

increased plant height, number of leaves/plant and foliage dry weight/ plant in both seasons (Table 1). Spraying strawberry plants with $\mathrm{Fe}$ at $0.4 \%$ was found the best treatment for growth (Ekka et al., 2018).

The interaction between fertilizing with vermicompost at $4.44 /$ fad., and foliar spray with $\mathrm{Fe}$ at $200 \mathrm{ppm}$ significantly increased plant height, number of leaves/plant and foliage dry weight/plant without significant differences with the interaction between fertilizing with chicken manure at 3.75 ton/fad., and foliar spray with $\mathrm{Fe}$ at $200 \mathrm{ppm}$ with respect to plant height in both seasons.

\section{$\mathrm{N}, \mathrm{P}, \mathrm{K}$ and protein contents in shoots}

Fertilizing with vermicompost at 4.44 ton/fad., increased N, P, K and total protein in shoots with no significant differences with fertilizing with chicken manure at 3.75 ton/fad., with respect N, P and total protein (Table 3).

Spraying plants with $\mathrm{Fe}$ at $200 \mathrm{ppm}$ gave the highest values of $\mathrm{N}, \mathrm{P}, \mathrm{K}$, total protein with no significant differences with $\mathrm{Zn}$ at $100 \mathrm{ppm}$ (Table 3).
The interaction between fertilizing with vermicompost at 4.44 ton/fad., and foliar spray with $\mathrm{Fe}$ at $200 \mathrm{ppm}$ increased $\mathrm{N}$ and total protein in shoots with no significant differences with the interaction between fertilizing with chicken manure at 3.75 ton/fad., and foliar spray with Fe at $200 \mathrm{ppm}$ with respect to $\mathrm{N}$ content in shoots (Table 4) .

\section{Yield and its Components}

Results in Table 5 show that fertilizing strawberry plants grown in sandy soil with vermicompost at 4.44 ton/fad., gave the highest value for each of average fruit weight, yield/ plant and total yield/fad., followed by fertilizing with chicken manure at 3.75 ton/fad., in both seasons. As for early yield, fertilizing with vermicompost at 4.44 ton/fad., and chicken manure at 3.75 ton/fad., increased early yield (ton/fad.). These results agree with those reported by Arancon et al. (2004) and Rajbir et al. (2008).

The positive effects of fertilizing with vermicompost on plant growth and yield of strawberry may be due to that: Vermicompost contains most nutrients in plant- available forms 
Table 2. Effect of interaction between organic manure and foliar spray with some microelements on growth parameters of strawberry plants at 120 days after transplanting in 2017/2018 and 2018/2019 seasons

\begin{tabular}{|c|c|c|c|c|c|c|c|}
\hline \multicolumn{2}{|l|}{$\overline{\text { Treatment }}$} & \multicolumn{2}{|c|}{ Plant height $(\mathrm{cm})$} & \multicolumn{2}{|c|}{ Leaf number/plant } & \multicolumn{2}{|c|}{ Foliage dry weight (g) } \\
\hline$\overline{\text { Organic manure }}$ & Microelement & $\begin{array}{c}1^{\text {st }} \\
\text { season }\end{array}$ & $\begin{array}{c}2^{\text {nd }} \\
\text { season }\end{array}$ & $\begin{array}{c}1^{\text {st }} \\
\text { season }\end{array}$ & $\begin{array}{c}2^{\text {nd }} \\
\text { season }\end{array}$ & $\begin{array}{c}1^{\text {st }} \\
\text { season }\end{array}$ & $\begin{array}{c}2^{\text {nd }} \\
\text { season }\end{array}$ \\
\hline & Control & 13.66 & 12.00 & 22.16 & 23.66 & 20.16 & 20.83 \\
\hline & B at 25 ppm & 15.00 & 14.16 & 27.66 & 28.00 & 33.27 & 34.60 \\
\hline \multirow[t]{4}{*}{ Chicken manure } & Zn at $100 \mathrm{ppm}$ & 16.83 & 15.66 & 26.50 & 26.66 & 35.85 & 36.60 \\
\hline & Fe at $200 \mathrm{ppm}$ & 17.66 & 18.00 & 27.00 & 27.83 & 36.94 & 38.12 \\
\hline & Control & 14.00 & 14.33 & 25.66 & 25.16 & 25.51 & 24.83 \\
\hline & B at $25 \mathrm{ppm}$ & 16.00 & 16.22 & 27.66 & 28.45 & 34.41 & 34.60 \\
\hline \multirow[t]{4}{*}{ Vermicompost } & Zn at $100 \mathrm{ppm}$ & 18.03 & 17.66 & 28.00 & 28.83 & 36.94 & 38.11 \\
\hline & Fe at $200 \mathrm{ppm}$ & 18.66 & 18.00 & 29.50 & 30.66 & 41.85 & 42.60 \\
\hline & Control & 11.66 & 10.00 & 22.16 & 22.66 & 17.16 & 16.83 \\
\hline & B at 25 ppm & 14.33 & 13.66 & 23.50 & 23.43 & 28.32 & 28.80 \\
\hline \multirow[t]{2}{*}{ Compost } & $\mathrm{Zn}$ at $100 \mathrm{ppm}$ & 14.66 & 13.16 & 23.66 & 23.83 & 29.30 & 30.29 \\
\hline & Fe at $200 \mathrm{ppm}$ & 16.16 & 15.16 & 25.00 & 25.66 & 32.17 & 33.25 \\
\hline LSD 0.05 & & 1.50 & 1.06 & 0.74 & 1.98 & 1.59 & 1.54 \\
\hline
\end{tabular}

Quantity of chicken manure, vermicompost and compost were about 3.75, 4.44 and 7.50 ton/fad.

Table 3. Effect of organic manure and foliar spray with some microelements on chemical composition of strawberry shoots at 120 days after transplanting during 2018/2019 season

\begin{tabular}{lcccccc}
\hline Treatment & $\mathbf{N}(\%)$ & $\mathbf{P}(\%)$ & $\mathbf{K}(\%)$ & Total protein (\%) & Fe (ppm) & B ppm \\
\hline Chicken manure & 2.43 & 0.093 & 1.38 & 15.24 & 132.21 & 2.39 \\
Vermicompost & 2.53 & 0.090 & 1.87 & 15.81 & 110.51 & 1.61 \\
Compost & 2.06 & 0.088 & 1.32 & 12.92 & 121.33 & 6.79 \\
LSD at 0.05 level & $\mathbf{0 . 1 5}$ & $\mathbf{0 . 0 0 2}$ & $\mathbf{0 . 1 0}$ & $\mathbf{0 . 9 4}$ & $\mathbf{6 . 5 4}$ & $\mathbf{0 . 3 2}$ \\
& & & Microelement (ppm) & & \\
Control & 2.10 & 0.096 & 1.39 & 13.17 & 98.83 & 3.10 \\
B at 25 & 2.31 & 0.083 & 1.52 & 14.48 & 119.07 & 3.45 \\
Zn at 100 & 2.42 & 0.091 & 1.55 & 15.12 & 123.96 & 5.39 \\
Fe at 200 & 2.53 & 0.091 & 1.63 & 15.85 & 143.53 & 2.44 \\
LSD 0.05 & $\mathbf{0 . 1 3}$ & $\mathbf{0 . 0 0 4}$ & $\mathbf{0 . 0 8}$ & $\mathbf{0 . 8 2}$ & $\mathbf{5 . 7 1}$ & $\mathbf{0 . 2 8}$ \\
\hline
\end{tabular}

Quantity of chicken manure, vermicompost and compost were about 3.75, 4.44 and 7.50 ton/fad. 
Table 4. Effect of the interaction between organic manure and foliar spray with some microelements on chemical composition of strawberry shoots at 120 days after transplanting during 2018/2019 season

\begin{tabular}{|c|c|c|c|c|c|c|c|}
\hline \multicolumn{2}{|l|}{ Treatment } & \multirow[t]{2}{*}{$\mathbf{N}(\%)$} & \multirow[t]{2}{*}{$\mathbf{P}(\%)$} & \multirow[t]{2}{*}{$\mathrm{K}(\%)$} & \multirow[t]{2}{*}{ Total protein (\%) } & \multirow[t]{2}{*}{$\mathrm{Fe}(\mathrm{ppm})$} & \multirow[t]{2}{*}{ B ppm } \\
\hline Organic manure & Microelement & & & & & & \\
\hline & Control & 2.14 & 0.101 & 1.31 & 13.38 & 121.42 & 1.55 \\
\hline & B at 25 ppm & 2.46 & 0.080 & 1.32 & 15.39 & 138.05 & 3.47 \\
\hline \multirow[t]{4}{*}{ Chicken manure } & $\mathrm{Zn}$ at $100 \mathrm{ppm}$ & 2.52 & 0.103 & 1.43 & 15.75 & 129.34 & 2.00 \\
\hline & Fe at $200 \mathrm{ppm}$ & 2.63 & 0.090 & 1.46 & 16.44 & 140.04 & 2.57 \\
\hline & Control & 2.28 & 0.097 & 1.67 & 14.25 & 101.20 & 1.70 \\
\hline & B at 25 ppm & 2.48 & 0.085 & 1.88 & 15.50 & 98.51 & 2.96 \\
\hline \multirow[t]{4}{*}{ Vermicompost } & Zn at $100 \mathrm{ppm}$ & 2.62 & 0.089 & 1.88 & 16.38 & 112.58 & 1.05 \\
\hline & Fe at $200 \mathrm{ppm}$ & 2.74 & 0.090 & 2.07 & 17.13 & 129.74 & 0.73 \\
\hline & Control & 1.90 & 0.090 & 1.21 & 11.88 & 73.88 & 6.05 \\
\hline & B at 25 ppm & 2.01 & 0.086 & 1.37 & 12.56 & 120.65 & 9.76 \\
\hline \multirow[t]{2}{*}{ Compost } & $\mathrm{Zn}$ at $100 \mathrm{ppm}$ & 2.12 & 0.083 & 1.34 & 13.25 & 129.96 & 7.32 \\
\hline & Fe at $200 \mathrm{ppm}$ & 2.24 & 0.094 & 1.38 & 14.00 & 160.81 & 4.04 \\
\hline LSD 0.05 & & 0.22 & 0.007 & 0.15 & 1.42 & 9.90 & 0.49 \\
\hline
\end{tabular}

Quantity of chicken manure, vermicompost and compost were about 3.75, 4.44 and 7.50 ton/fad.

Table 5. Effect of organic manure and foliar spray with some microelements on yield and its components and deformed fruits of strawberry during 2017/2018 and 2018/2019 seasons

\begin{tabular}{|c|c|c|c|c|c|c|c|c|c|c|}
\hline \multirow[t]{2}{*}{ Treatment } & \multicolumn{2}{|c|}{$\begin{array}{c}\text { Average fruit } \\
\text { weight (g) }\end{array}$} & \multicolumn{2}{|c|}{$\begin{array}{c}\text { Yield / plant } \\
(\mathrm{g})\end{array}$} & \multicolumn{2}{|c|}{$\begin{array}{c}\text { Early yield } \\
\text { (ton/fad.) }\end{array}$} & \multicolumn{2}{|c|}{$\begin{array}{c}\begin{array}{c}\text { Total yield } \\
\text { (ton/fad.) }\end{array} \\
\end{array}$} & \multicolumn{2}{|c|}{$\begin{array}{c}\text { Deformed fruits } \\
(\%)\end{array}$} \\
\hline & $\begin{array}{c}1^{\text {st }} \\
\text { season }\end{array}$ & $\begin{array}{c}2^{\text {nd }} \\
\text { season }\end{array}$ & $\begin{array}{c}1^{\text {st }} \\
\text { season }\end{array}$ & $\begin{array}{c}2^{\text {nd }} \\
\text { season }\end{array}$ & $\begin{array}{c}1^{\text {st }} \\
\text { season }\end{array}$ & $\begin{array}{c}2^{\text {nd }} \\
\text { season }\end{array}$ & $\begin{array}{c}1^{\text {st }} \\
\text { season } \\
\end{array}$ & $\begin{array}{c}2^{\text {nd }} \\
\text { season }\end{array}$ & $\begin{array}{c}1^{\text {st }} \\
\text { season }\end{array}$ & $\begin{array}{c}2^{\text {nd }} \\
\text { season }\end{array}$ \\
\hline & \multicolumn{10}{|c|}{ Organic manure source } \\
\hline Chicken manure & 20.94 & 21.81 & 302.45 & 300.20 & 4.226 & 4.162 & 14.442 & 14.444 & 5.31 & 6.17 \\
\hline Vermicompost & 22.62 & 22.53 & 323.76 & 318.48 & 4.446 & 4.362 & 15.473 & 15.111 & 3.83 & 4.69 \\
\hline Compost & 17.59 & 16.63 & 211.13 & 190.23 & 2.836 & 2.628 & 9.779 & 8.752 & 4.67 & 5.69 \\
\hline \multirow[t]{2}{*}{ LSD at 0.05 level } & 1.07 & 0.73 & 7.52 & 9.81 & 0.392 & 0.425 & 0.654 & 0.981 & 0.40 & 0.11 \\
\hline & \multicolumn{10}{|c|}{ Microelement (ppm) } \\
\hline Control & 18.19 & 18.26 & 209.75 & 199.81 & 2.929 & 2.847 & 10.025 & 9.591 & 6.33 & 7.42 \\
\hline B at 25 & 19.98 & 19.59 & 268.70 & 240.11 & 3.873 & 3.457 & 12.899 & 11.625 & 3.28 & 3.97 \\
\hline $\mathrm{Zn}$ at 100 & 20.59 & 21.09 & 293.27 & 298.13 & 4.084 & 4.047 & 13.933 & 13.922 & 4.17 & 5.08 \\
\hline Fe at 200 & 22.77 & 22.35 & 344.73 & 340.51 & 4.458 & 4.519 & 16.068 & 15.937 & 4.64 & 5.58 \\
\hline LSD at 0.05 level & 0.93 & 0.64 & 6.57 & 8.57 & 0.343 & 0.269 & 0.571 & 0.857 & 0.33 & 0.29 \\
\hline
\end{tabular}

Quantity of chicken manure, vermicompost and compost were about 3.75, 4.44 and 7.50 ton/fad.

Fad. $=4200 \mathrm{~m} 2=0.42$ ha. 
such as nitrates, phosphates and exchangeable calcium and soluble potassium (Orozco et al., 1996; Edwards, 1998). Vermicompost have a large particulate surface areas that provide many microsites for microbial activity and for strong retention of nutrients (Shi-wei and Fu-zhen, 1991), vermicompost are rich in microbial population and diversity, particularly fungi, bacteria and actinomycetes (Tomati et al. 1988, and Edwards, 1998). Vermicompost contain plant growth regulators and other plant growth influencing material produced by microorganisms (Grappelli et al., 1987; Tomati et al., 1988) including humates (Atiyeh et al., 2002).

Spraying strawberry plants with B at $25 \mathrm{ppm}$, $\mathrm{Zn}$ at $100 \mathrm{ppm}$ and $\mathrm{Fe}$ at $200 \mathrm{ppm}$ increased yield and its components compared to control (spraying with tap water) in both seasons. Foliar spray with Fe at $200 \mathrm{ppm}$ increased average fruit weight, yield/plant, early yield and total yield /fad., followed by foliar spray with $\mathrm{Zn}$ at 100 ppm in both seasons (Table 5). Spraying plants with $\mathrm{Fe}$ at $0.4 \%$ was found the best treatment for yield of strawberry (Ekka et al. 2018).

Iron acts as catalyst in synthesis of chlorophyll molecule and helps the absorption of other elements. It is a key element in various redox reactions of respiration, photosynthesis and reduction of nitrates and sulphates (Wallihan et al. 1958; Zende, 1996).

The interaction between fertilizing with vermicompost at 4.44 ton/fad. and foliar spray with $\mathrm{Fe}$ at $200 \mathrm{ppm}$ and the interaction between fertilizing with chicken manure at 3.75 ton/fad., and foliar spray with $\mathrm{Fe}$ at $200 \mathrm{ppm}$ increased average fruit weight, yield per plant, early yield and total yield/fad., in both seasons (Table 6).

As for deformed fruits percentage, fertilizing with vermicompost at $4.44 \mathrm{ton} / \mathrm{fad}$. gave the lowest values of deformed fruits (\%) compared to chicken manure and compost in both seasons. Spraying with B at $25 \mathrm{ppm}, \mathrm{Zn}$ at $100 \mathrm{ppm}$ and $\mathrm{Fe}$ at $200 \mathrm{ppm}$ decreased deformed fruits (\%) compared to control (spraying with tap water. Boron at $25 \mathrm{ppm}$ recorded minimum values of deformed fruits (\%) followed by spraying plants with $\mathrm{Zn}$ at $100 \mathrm{ppm}$. The interaction between fertilizing with vermicompost at 4.44 ton/fad., and spraying with $B$ at $25 \mathrm{ppm}$ gave the lowest values of deformed fruits (\%) in both seasons.

Boron has an effect on cell wall structure, cell elongation (pollen tube) and root growth (Barker and Pilbeam, 2006). Zinc reduces pollen tube growth through functioning tryptophan as an auxin precursor biosynthesis (Chaplin and Westwood, 1980).

\section{Fruit Quality at Harvest}

Fertilizing strawberry plants with vermicompost at $4.44 \mathrm{ton} / \mathrm{fad}$. increased fruit firmness, TSS and Vit C in strawberry fruits, whereas fertilizing with compost at 7.50 ton/fad. increased total acidity in fruits at harvest in both seasons (Table 7). Fertilizing with vermicompost at 7.5 ton/ha. increased firmness, total soluble solids and ascorbic acid content of strawberry (Rajbir et al., 2008).

Foliar spray with B at $25 \mathrm{ppm}$ increased fruit firmness, TSS and Vit. C in fruits, at harvest in both seasons. Sprayed plants with tap water control increased total acidity in fruits (Table 7). Maximum ascorbic acid values were noticed with $\mathrm{Fe}$ at $0.04 \%$ compared to control (Ekka $\boldsymbol{e t}$ al., 2018)

Boron is essential for translocation of sugar, starch, nitrogen, phosphorus, certain hormone, synthesis of amino acids and protein, regulation of carbohydrate metabolism as well as development of phloem.

The interaction between fertilizing with vermicompost at $4.44 \mathrm{ton} / \mathrm{fad}$. and foliar spray with B at $25 \mathrm{ppm}$ increased fruit firmness, TSS and Vit. C in fruits at harvest in both seasons. Fertilizing with compost at 7.50 ton/fad. and spraying with tap water (control) increased total acidity in fruits (Table 8).

\section{Fe and $B$ Contents in Fruits at Harvest}

The obtained results in Table 9 illustrate that fertilizing with chicken manure at 3.75 ton/fad., increased $\mathrm{Fe}$ content in strawberry fruits, whereas fertilizing with compost at 7.50 ton/ fad., increased B content in strawberry fruits. Spraying plants with $\mathrm{Fe}$ at $200 \mathrm{ppm}$ gave the highest values of $\mathrm{Fe}$ in content strawberry fruits, whereas spraying with $\mathrm{Zn}$ at $100 \mathrm{ppm}$ increased B content in strawberry fruits (Table 9). 
Table 6. Effect of the interaction between organic manure and foliar spray with some microelements on yield and its components and deformed fruits of strawberry during $2017 / 2018$ and 2018/2019 seasons

\begin{tabular}{|c|c|c|c|c|c|c|c|c|c|c|c|}
\hline \multirow{2}{*}{$\begin{array}{l}\text { Treatment } \\
\text { Organic manure }\end{array}$} & \multirow[b]{2}{*}{ Microelement } & \multicolumn{2}{|c|}{$\begin{array}{c}\text { Average fruit } \\
\text { weight (g) }\end{array}$} & \multicolumn{2}{|c|}{ Yield/plant (g) } & \multicolumn{2}{|c|}{$\begin{array}{l}\text { Early yield } \\
\text { (ton/fad.) }\end{array}$} & \multicolumn{2}{|c|}{$\begin{array}{l}\text { Total yield } \\
\text { (ton/fad.) }\end{array}$} & \multicolumn{2}{|c|}{$\begin{array}{l}\text { Deformed } \\
\text { fruits }(\%)\end{array}$} \\
\hline & & $\begin{array}{c}1^{\text {st }} \\
\text { season }\end{array}$ & $\begin{array}{c}2^{\text {nd }} \\
\text { season } \\
\end{array}$ & $\begin{array}{c}1^{\text {st }} \\
\text { season }\end{array}$ & $\begin{array}{c}2^{\text {nd }} \\
\text { season }\end{array}$ & $\begin{array}{c}1^{\text {st }} \\
\text { season }\end{array}$ & $\begin{array}{c}2^{\text {nd }} \\
\text { season }\end{array}$ & $\begin{array}{c}1^{\text {st }} \\
\text { season }\end{array}$ & $\begin{array}{c}2^{\text {nd }} \\
\text { season }\end{array}$ & $\begin{array}{c}1^{\text {st }} \\
\text { season }\end{array}$ & $\begin{array}{c}2^{\text {nd }} \\
\text { season }\end{array}$ \\
\hline & Control & 18.27 & 19.31 & 223.81 & 230.33 & 3.101 & 3.220 & 10.473 & 11.056 & 7.75 & 9.00 \\
\hline & B at 25 ppm & 20.74 & 20.44 & 298.14 & 275.14 & 4.299 & 3.866 & 14.316 & 13.206 & 3.50 & 4.17 \\
\hline & $\mathrm{Zn}$ at $100 \mathrm{ppm}$ & 21.46 & 23.09 & 309.21 & 325.11 & 4.454 & 4.385 & 14.833 & 15.600 & 4.83 & 5.50 \\
\hline \multirow[t]{4}{*}{ Chicken manure } & Fe at $200 \mathrm{ppm}$ & 23.30 & 24.41 & 378.62 & 370.23 & 5.050 & 5.180 & 18.147 & 17.915 & 5.17 & 6.00 \\
\hline & Control & 20.38 & 20.18 & 235.32 & 220.57 & 3.334 & 3.180 & 11.436 & 10.589 & 5.00 & 5.75 \\
\hline & B at $25 \mathrm{ppm}$ & 22.13 & 22.27 & 317.14 & 295.41 & 4.571 & 4.356 & 15.222 & 14.507 & 2.83 & 3.50 \\
\hline & Zn at $100 \mathrm{ppm}$ & 23.17 & 23.40 & 350.45 & 365.78 & 4.753 & 4.828 & 16.827 & 16.410 & 3.50 & 4.50 \\
\hline \multirow[t]{5}{*}{ Vermicompost } & ppm & 24.82 & 24.29 & 392.14 & 392.17 & 5.128 & 5.087 & 18.407 & 18.937 & 4.00 & 5.00 \\
\hline & Control & 15.93 & 15.31 & 170.13 & 148.52 & 2.352 & 2.141 & 8.166 & 7.128 & 6.25 & 7.50 \\
\hline & B at 25 ppm & 17.07 & 16.08 & 190.81 & 149.79 & 2.750 & 2.151 & 9.159 & 7.163 & 3.50 & 4.25 \\
\hline & $\mathrm{Zn}$ at $100 \mathrm{ppm}$ & 17.15 & 16.79 & 220.15 & 203.49 & 3.045 & 2.929 & 10.140 & 9.755 & 4.17 & 5.25 \\
\hline & Fe at & 20.21 & 18.35 & 263.44 & 259.14 & 3.198 & 3.291 & 11.650 & 10.960 & 4.75 & 5.75 \\
\hline LSD at 0.05 level & & 1.62 & 1.10 & 11.38 & 14.85 & 0.594 & 0.467 & 0.990 & 1.485 & 0.57 & 0.50 \\
\hline
\end{tabular}

Quantity of chicken manure, vermicompost and compost were about 3.75, 4.44 and 7.50 ton/fad.

Table 7. Effect of organic manure and foliar spray with some microelements on fruit quality of strawberry at harvest during $2017 / 2018$ and $2018 / 2019$ seasons

\begin{tabular}{|c|c|c|c|c|c|c|c|c|}
\hline \multirow[t]{2}{*}{$\overline{\text { Treatment }}$} & \multicolumn{2}{|c|}{$\begin{array}{c}\text { Firmness } \\
\left(\mathrm{g} / \mathrm{cm}^{2}\right)\end{array}$} & \multicolumn{2}{|c|}{$\begin{array}{c}\text { TSS } \\
\left(\text { brix }^{0}\right)\end{array}$} & \multicolumn{2}{|c|}{$\begin{array}{c}\text { Total acidity } \\
\text { (mg/100 ml juice) }\end{array}$} & \multicolumn{2}{|c|}{$\begin{array}{c}\text { Vitamin C } \\
\text { (mg/100 ml juice) }\end{array}$} \\
\hline & $1^{\text {st }}$ season & $\begin{array}{c}2^{\text {nd }} \\
\text { season }\end{array}$ & $\begin{array}{c}1^{\text {st }} \\
\text { season }\end{array}$ & $\begin{array}{c}2^{\text {nd }} \\
\text { season }\end{array}$ & $\begin{array}{c}1^{\text {st }} \\
\text { season }\end{array}$ & $\begin{array}{c}2^{\text {nd }} \\
\text { season }\end{array}$ & $\begin{array}{c}1^{\text {st }} \\
\text { season }\end{array}$ & $\begin{array}{c}2^{\text {nd }} \\
\text { season }\end{array}$ \\
\hline & \multicolumn{8}{|c|}{ Organic manure source } \\
\hline Chicken manure & 450.1 & 454.7 & 9.59 & 9.32 & 0.63 & 0.69 & 39.33 & 40.06 \\
\hline Vermicompost & 473.4 & 501.9 & 9.96 & 10.00 & 0.60 & 0.61 & 45.79 & 45.54 \\
\hline Compost & 436.4 & 455.2 & 8.47 & 8.61 & 0.75 & 0.78 & 28.67 & 30.04 \\
\hline \multirow[t]{2}{*}{ LSD at 0.05 level } & 16.36 & 10.14 & 0.52 & 0.39 & 0.06 & 0.09 & 1.41 & 2.29 \\
\hline & \multicolumn{8}{|c|}{ Microelement (ppm) } \\
\hline Control & 342.8 & 356.9 & 7.98 & 8.01 & 0.80 & 0.80 & 33.42 & 35.03 \\
\hline B at 25 & 529.2 & 557.2 & 10.37 & 10.30 & 0.65 & 0.64 & 42.03 & 42.73 \\
\hline Zn at 100 & 459.2 & 467.0 & 9.31 & 9.39 & 0.65 & 0.73 & 37.53 & 37.67 \\
\hline Fe at 200 & 481.9 & 501.2 & 9.70 & 9.53 & 0.54 & 0.61 & 38.74 & 38.75 \\
\hline LSD at 0.05 level & 14.29 & 8.86 & 0.45 & 0.34 & 0.06 & 0.08 & 1.59 & 1.35 \\
\hline
\end{tabular}

Quantity of chicken manure, vermicompost and compost were about 3.75, 4.44 and 7.50 ton/fad. 
Table 8. Effect of the interaction between organic manure and foliar spray with some microelements on fruit quality of strawberry at harvest during 2017/2018 and 2018/ 2019 seasons

\begin{tabular}{|c|c|c|c|c|c|c|c|c|c|}
\hline \multirow{2}{*}{$\begin{array}{l}\text { Treatment } \\
\text { Organic manure }\end{array}$} & \multirow[b]{2}{*}{ Microelement } & \multicolumn{2}{|c|}{$\begin{array}{l}\text { Firmness } \\
\left(\mathrm{g} / \mathrm{cm}^{2}\right)\end{array}$} & \multicolumn{2}{|c|}{$\begin{array}{c}\text { TSS } \\
\left(\text { brix }^{0}\right)\end{array}$} & \multicolumn{2}{|c|}{$\begin{array}{c}\text { Total acidity } \\
\text { (mg/100 ml juice) }\end{array}$} & \multicolumn{2}{|c|}{$\begin{array}{c}\text { Vitamin C } \\
\text { (mg/100 ml juice) }\end{array}$} \\
\hline & & $\begin{array}{c}1^{\text {st }} \\
\text { season } \\
\end{array}$ & $\begin{array}{c}2^{\text {nd }} \\
\text { season } \\
\end{array}$ & $\begin{array}{c}1^{\text {st }} \\
\text { season } \\
\end{array}$ & $\begin{array}{c}2^{\text {nd }} \\
\text { season } \\
\end{array}$ & $\begin{array}{c}1^{\text {st }} \\
\text { season } \\
\end{array}$ & $\begin{array}{c}2^{\text {nd }} \\
\text { season } \\
\end{array}$ & $\begin{array}{c}1^{\text {st }} \\
\text { season } \\
\end{array}$ & $\begin{array}{c}2^{\text {nd }} \\
\text { season } \\
\end{array}$ \\
\hline & Control & 332.6 & 335.0 & 8.00 & 7.70 & 0.72 & 0.79 & 31.70 & 32.70 \\
\hline & B at $25 \mathrm{ppm}$ & 519.9 & 531.9 & 10.96 & 10.59 & 0.69 & 0.69 & 43.56 & 45.24 \\
\hline \multirow[t]{4}{*}{ Chicken manure } & Zn at 100 ppm & 467.9 & 472.0 & 9.60 & 9.20 & 0.61 & 0.76 & 40.44 & 41.16 \\
\hline & Fe at 200 ppm & 480.0 & 480.0 & 9.80 & 9.80 & 0.51 & 0.54 & 41.64 & 41.16 \\
\hline & Control & 352.0 & 376.0 & 8.80 & 9.10 & 0.72 & 0.69 & 41.40 & 43.56 \\
\hline & B at $25 \mathrm{ppm}$ & 583.9 & 619.9 & 10.99 & 10.86 & 0.51 & 0.56 & 50.40 & 49.56 \\
\hline \multirow[t]{4}{*}{ Vermicompost } & $\mathrm{Zn}$ at $100 \mathrm{ppm}$ & 469.9 & 479.9 & 9.69 & 10.01 & 0.62 & 0.62 & 43.96 & 42.44 \\
\hline & Fe at 200 ppm & 487.9 & 531.9 & 10.39 & 10.03 & 0.57 & 0.57 & 47.40 & 46.60 \\
\hline & Control & 343.9 & 359.9 & 7.14 & 7.25 & 0.96 & 0.92 & 27.16 & 28.84 \\
\hline & B at $25 \mathrm{ppm}$ & 483.9 & 519.9 & 9.18 & 9.46 & 0.76 & 0.67 & 32.15 & 33.41 \\
\hline \multirow[t]{2}{*}{ Compost } & Zn at 100 ppm & 439.9 & 449.3 & 8.64 & 8.97 & 0.74 & 0.81 & 28.19 & 29.42 \\
\hline & Fe at 200 ppm & 477.9 & 491.8 & 8.92 & 8.77 & 0.56 & 0.72 & 27.18 & 28.49 \\
\hline LSD at 0.05 level & & 24.76 & 15.35 & 0.79 & 0.59 & 0.09 & 0.14 & 2.75 & 2.34 \\
\hline
\end{tabular}

Quantity of chicken manure, vermicompost and compost were about 3.75, 4.44 and 7.50 ton/fad.

Table 9. Effect of organic manure and foliar spray with some microelements on iron and boron contents of strawberry fruits at harvest during 2018/2019 season

\begin{tabular}{lcc}
\hline Treatment & Fe (ppm) & B (ppm) \\
\hline & \multicolumn{2}{c}{ Organic manure source } \\
Chicken manure & 132.21 & 2.39 \\
Vermicompost & 110.51 & 1.61 \\
Compost & 121.33 & 6.79 \\
LSD at 0.05 level & $\mathbf{6 . 5 4}$ & $\mathbf{0 . 3 2}$ \\
& & Microelement (ppm) \\
Control & 98.83 & 3.10 \\
B at 25 & 119.07 & 3.45 \\
Zn at 100 & 123.96 & 5.39 \\
Fe at 200 & 143.53 & 2.44 \\
LSD 0.05 & $\mathbf{5 . 7 1}$ & $\mathbf{0 . 2 8}$ \\
\hline
\end{tabular}


The interaction between fertilizing with compost at 7.50 ton/fad., and foliar spray with $\mathrm{Fe}$ at $200 \mathrm{ppm}$ increased Fe content in strawberry fruits, whereas the interaction between fertilizing with compost at 7.50 ton/ fad., and foliar spray with $\mathrm{B}$ at $25 \mathrm{ppm}$ increased $\mathrm{B}$ content in strawberry fruits (Table 10).

\section{Storability}

\section{Fruit weight loss (\%) and Decay (\%)}

Fruit weight loss (\%) and decay (\%) increased with increasing cold storage periods. Fertilizing with vermicompost at 4.44 ton/fad., gave the lowest value for each of fruit weight loss (\%) and decay (\%), whereas fertilizing with compost at $7.5 \mathrm{ton} / \mathrm{fad}$., gave the highest value for each of weight loss (\%) and decay (\%) during cold storage periods in both seasons (Tables 11 and 12).
Spraying strawberry plants with B at $25 \mathrm{ppm}$, $\mathrm{Zn}$ at $100 \mathrm{ppm}$ and $\mathrm{Fe}$ at $200 \mathrm{ppm}$ recorded the minimum value for each of fruit weight loss (\%) and decay (\%) compared to control (spraying with tap water). Spraying with $\mathrm{Zn}$ at $100 \mathrm{ppm}$ and $\mathrm{Fe}$ at $200 \mathrm{ppm}$ decreased weight loss (\%) and decay (\%) in fruits during cold storage periods (Tables 11 and 12).

The interaction between fertilizing with vermicompost at 4.44 ton/fad., and foliar spray with $\mathrm{Zn}$ at $100 \mathrm{ppm}$ decreased weight loss (\%) and decay (\%) in fruits during cold storage periods, followed by the interaction between fertilizing with vermicompost at 4.44 ton/fad., and foliar spray with $\mathrm{Fe}$ at $200 \mathrm{ppm}$ (Tables 13 and 14).

Table 10. Effect of the interaction between organic manure and foliar spray with some microelements on iron and boron contents of strawberry fruits at harvest during 2018/2019 season

\begin{tabular}{|c|c|c|c|}
\hline \multicolumn{2}{|r|}{ Treatment } & \multirow[t]{2}{*}{$\mathrm{Fe}(\mathrm{ppm})$} & \multirow[t]{2}{*}{ B (ppm) } \\
\hline$\overline{\text { Organic manure }}$ & Microelement & & \\
\hline & Control & 121.42 & 1.55 \\
\hline & B at 25 ppm & 138.05 & 3.47 \\
\hline \multirow[t]{4}{*}{ Chicken manure } & $\mathrm{Zn}$ at $100 \mathrm{ppm}$ & 129.34 & 2.00 \\
\hline & Fe at $200 \mathrm{ppm}$ & 140.04 & 2.57 \\
\hline & Control & 101.20 & 1.70 \\
\hline & B at 25 ppm & 98.51 & 2.96 \\
\hline \multirow[t]{4}{*}{ Vermicompost } & $\mathrm{Zn}$ at $100 \mathrm{ppm}$ & 112.58 & 1.05 \\
\hline & Fe at $200 \mathrm{ppm}$ & 129.74 & 0.73 \\
\hline & Control & 73.88 & 6.05 \\
\hline & B at 25 ppm & 120.65 & 9.76 \\
\hline \multirow[t]{2}{*}{ Compost } & $\mathrm{Zn}$ at $100 \mathrm{ppm}$ & 129.96 & 7.32 \\
\hline & Fe at $200 \mathrm{ppm}$ & 160.81 & 4.04 \\
\hline LSD 0.05 & & 9.90 & 0.49 \\
\hline
\end{tabular}

Quantity of chicken manure, vermicompost and compost were about 3.75, 4.44 and 7.50 ton/fad. 
Zagazig J. Agric. Res., Vol. 47 No. (1) 2020

Table 11. Effect of the interaction between organic manure and foliar spray with some microelements on fruit weight loss (\%) of strawberry during storage period during 2017/2018 and 2018/2019 seasons

\begin{tabular}{|c|c|c|c|c|c|c|}
\hline \multirow[t]{4}{*}{ Treatment } & \multicolumn{6}{|c|}{ Weigh loss (\%) } \\
\hline & \multicolumn{6}{|c|}{ Storage periods (day) } \\
\hline & \multicolumn{2}{|c|}{5 days } & \multicolumn{2}{|c|}{10 days } & \multicolumn{2}{|c|}{15 days } \\
\hline & $\begin{array}{c}1^{\text {st }} \\
\text { season } \\
\end{array}$ & $\begin{array}{c}2^{\text {nd }} \\
\text { season } \\
\end{array}$ & $\begin{array}{c}1^{\text {st }} \\
\text { season }\end{array}$ & $\begin{array}{c}2^{\text {nd }} \\
\text { season }\end{array}$ & $\begin{array}{c}1^{\text {st }} \\
\text { season }\end{array}$ & $\begin{array}{c}2^{\text {nd }} \\
\text { season }\end{array}$ \\
\hline & \multicolumn{6}{|c|}{ Organic manure source } \\
\hline Chicken manure & 1.26 & 1.28 & 1.89 & 1.85 & 3.13 & 3.21 \\
\hline Vermicompost & 0.99 & 0.95 & 1.40 & 1.22 & 2.20 & 2.33 \\
\hline Compost & 1.56 & 1.59 & 2.48 & 2.44 & 3.51 & 3.60 \\
\hline \multirow[t]{2}{*}{ LSD at 0.05 level } & 0.16 & 0.24 & 0.17 & 0.25 & 0.32 & 0.42 \\
\hline & \multicolumn{6}{|c|}{ Microelement (ppm) } \\
\hline Control & 1.59 & 1.62 & 2.61 & 2.42 & 3.84 & 3.98 \\
\hline B at 25 & 1.35 & 1.34 & 2.06 & 1.97 & 3.13 & 3.22 \\
\hline $\mathrm{Zn}$ at 100 & 1.03 & 1.06 & 1.44 & 1.46 & 2.34 & 2.35 \\
\hline Fe at 200 & 1.11 & 1.08 & 1.57 & 1.50 & 2.48 & 2.65 \\
\hline LSD at 0.05 level & 0.14 & 0.21 & 0.15 & 0.22 & 0.28 & 0.37 \\
\hline
\end{tabular}

Quantity of chicken manure, vermicompost and compost were about 3.75, 4.44 and 7.50 ton/fad.

Table 12. Effect of the interaction between organic manure and foliar spray with some microelements on fruit weight loss (\%) of strawberry during storage periods in 2017/ 2018 and $2018 / 2019$ seasons

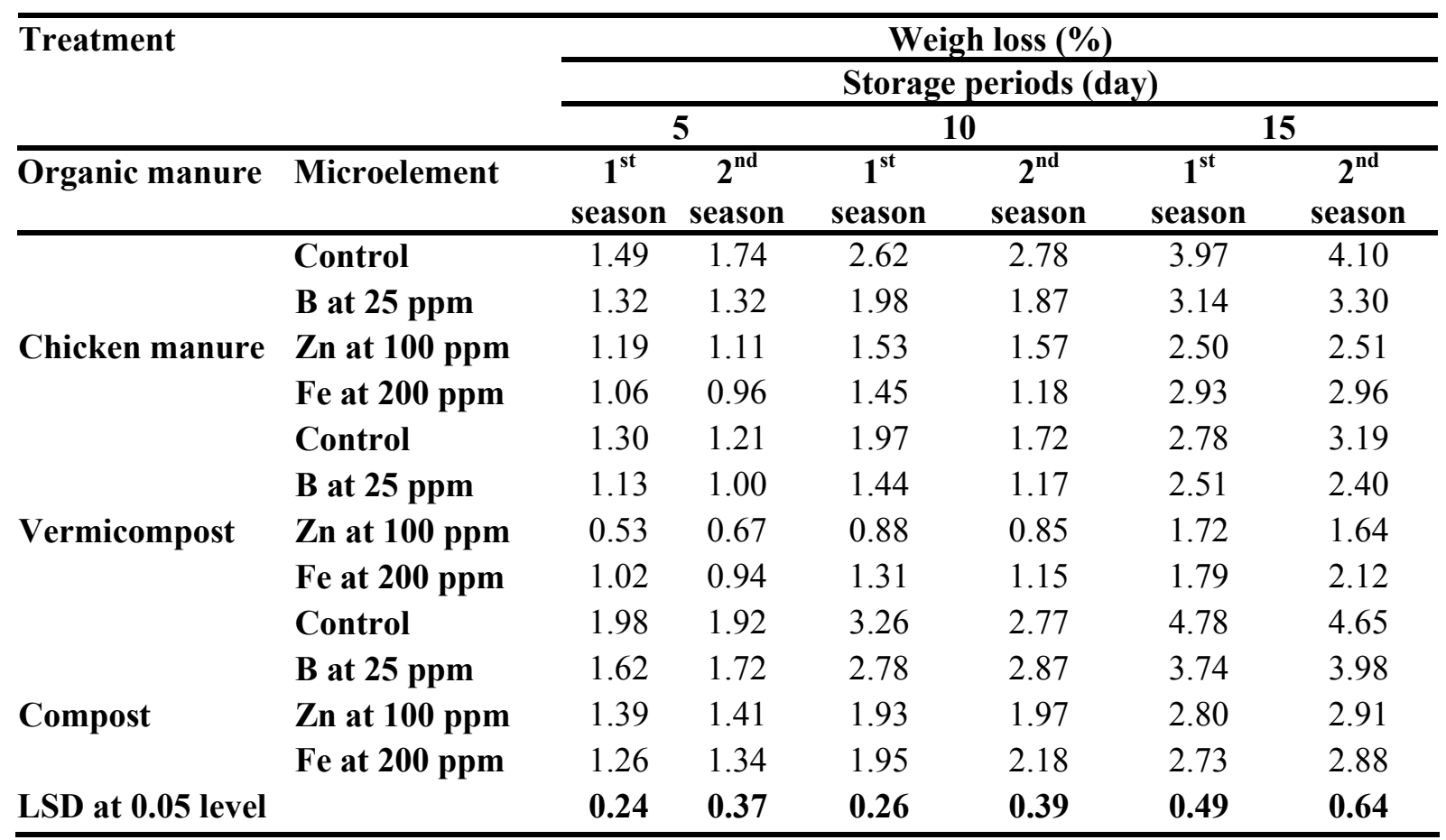

Quantity of chicken manure, vermicompost and compost were about 3.75, 4.44 and 7.50 ton/fad. 
Table 13. Effect of organic manure and foliar spray with some microelements on decay (\%) of strawberry fruits during storage periods in 2017/2018 and 2018/2019 seasons

\begin{tabular}{lcccccc}
\hline Treatment & \multicolumn{7}{c}{ Decay (\%) } \\
\cline { 2 - 7 } & \multicolumn{7}{c}{ Storage periods (day) } \\
\cline { 2 - 7 } & \multicolumn{7}{c}{$\mathbf{5}$} & \multicolumn{10}{c}{$\mathbf{1 0}$} \\
\cline { 2 - 7 } & $\mathbf{1}^{\text {st }}$ & $\mathbf{2}^{\text {nd }}$ & $\mathbf{1}^{\text {st }}$ & $\mathbf{2}^{\text {nd }}$ & $\mathbf{1}^{\text {st }}$ & $\mathbf{2}^{\text {nd }}$ \\
& season & season $^{\text {season }}$ & season $^{\text {season }}$ & season \\
\hline & & \multicolumn{5}{c}{ Organic manure source } \\
Chicken manure & 9.30 & 9.28 & 14.42 & 13.82 & 22.80 & 22.79 \\
Vermicompost & 7.96 & 7.64 & 11.20 & 9.78 & 17.60 & 18.70 \\
Compost & 12.50 & 12.78 & 19.84 & 19.91 & 28.10 & 28.84 \\
LSD at 0.05 level & $\mathbf{0 . 6 8}$ & $\mathbf{2 . 3 5}$ & $\mathbf{2 . 6 5}$ & $\mathbf{1 . 9 3}$ & $\mathbf{1 . 6 7}$ & $\mathbf{2 . 0 7}$ \\
& & & Microelement (ppm) & & \\
Control & 11.63 & 11.68 & 19.94 & 18.52 & 27.71 & 31.37 \\
B at 25 & 10.85 & 10.77 & 16.53 & 15.76 & 25.04 & 22.34 \\
Zn at 100 & 8.29 & 8.50 & 11.57 & 11.70 & 18.72 & 18.82 \\
Fe at 200 & 8.90 & 8.64 & 12.56 & 12.02 & 19.86 & 21.22 \\
LSD at 0.05 level & $\mathbf{0 . 8 2}$ & $\mathbf{1 . 7 3}$ & $\mathbf{1 . 9 8}$ & $\mathbf{2 . 0 8}$ & $\mathbf{0 . 9 1}$ & $\mathbf{2 . 1 1}$ \\
\hline
\end{tabular}

Table 14. Effect of the interaction between organic manure and foliar spray with some microelements on decay $(\%)$ of strawberry fruits during storage periods in 2017/2018 and 2018/2019 seasons

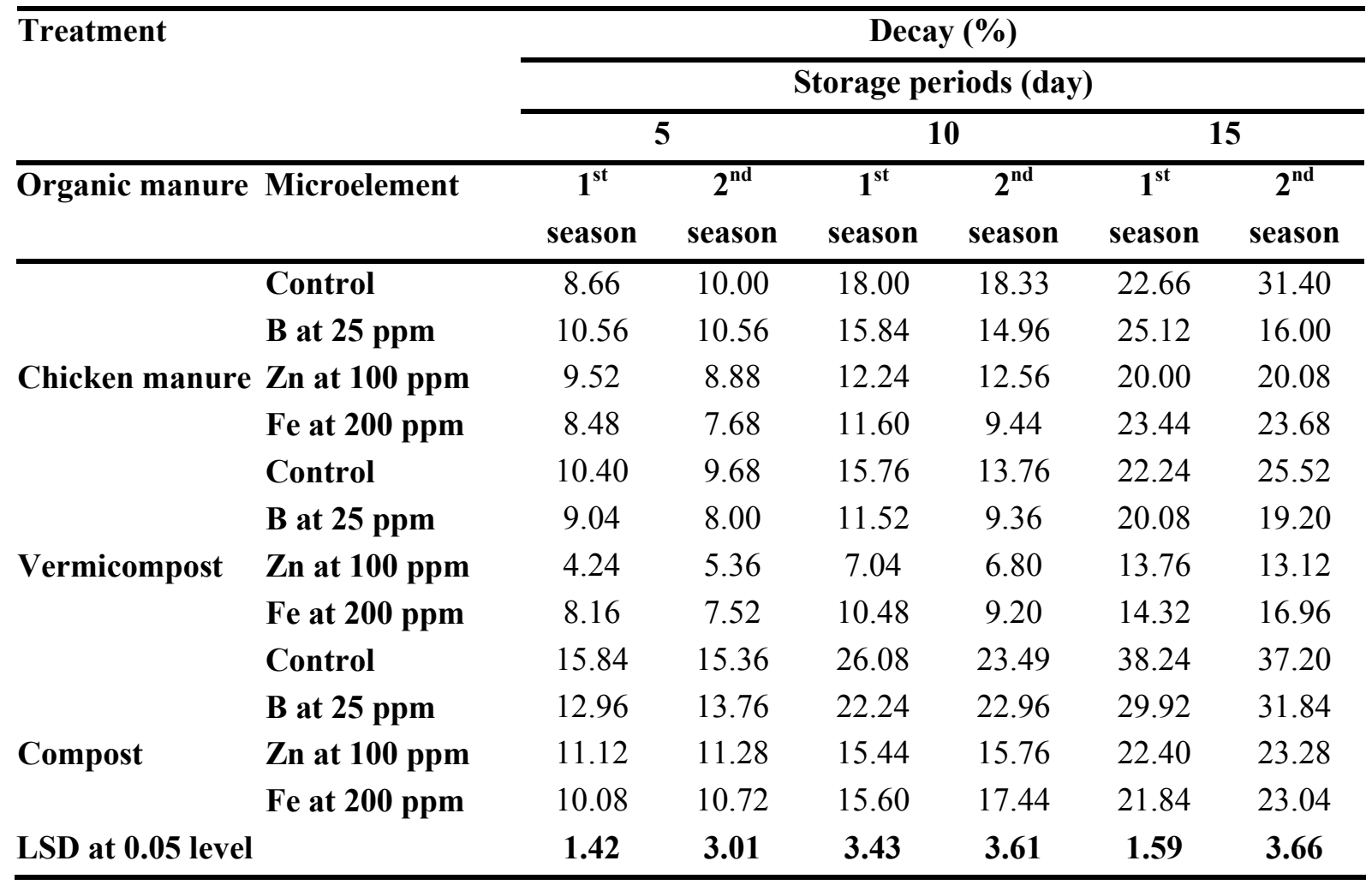




\section{REFERENCES}

AOAC (2005). Association of Official Analytical Chemists- International. Official Methods of Analysis, $18^{\text {th }}$ Ed., eds: W. Hortwitz, G.W. Latimer, AOAC- Int. Suite 500, 481 North Frederisk Avenue, Gaithersburg, Maryland, USA.

Arancon, N.Q., C.A. Edwards, P. Bierman, C. Welch and J.D. Metzer (2004). Influence of vermicomposts on field strawberries: effect on growth and yields. Bioresour. Technol., 93: $145-153$.

Atiyeh, R.M., S. Lee, C.A. Edwards, N.Q. Arancon and J.D. Metzger (2002). The influence of humic acids derived from earthworm-processed organic wastes on plant growth. Bioresour Technol., 84:7-14.

Barker, A.V. and D.J. Pilbeam (2006). Handbook of Plant Nutrition. CRC Press, Boca Raton, Florida, 3-13.

Chaplin, M.H. and M.N. Westwood (1980). Relationship of nutritional factors to fruit set. J. Plant Nut., 2 (4): 477-505.

Edwards, C.A. and I. Burrows (1988). The Potential of Earthworm Composts as Plant Growth Media. In: Edwards, C.A., Neuhauser, (Eds.), Earthworms in Environmental and Waste Management. SPB Academic Publ. b.v., The Netherlands, 211-220.

Edwards, C.A. (1998). The Use of Earthworms in the Breakdown and Management of Organic Wastes. In: Edwards CA (ed) Earthworm Ecology. CRC Press, Boca Raton, 327-354.

Ekka, R.A., A. Kerketta, S. Lakra and S. Saravanan (2018). Effect of Zn, B, Cu and Fe on vegetative growth, yield and quality of strawberry (Fragaria x ananassa Duch.) cv. Chandler. Int. J. Curr. Microbiol. App. Sci., 7: 2886-2890.

Evenhuis, B. and P.W. De Waard (1980). Principles and practices in plant analysis. FAO. Soil Bull., 39 (1): 152-162

Grappelli, A., E. Galli and U. Tomati (1987).
Earthworm casting effect on Agaricus bisporus fructification. Agrochimica, 2: $457-$ 462.

Lee, L.K. (1992). A perspective on the economic impacts of reducing agricultural chemical use. Ame. J. Alternative Agric., 7 : $82-88$.

Nour, E.M.E. (1999). Effect of some agricultural treatments on pea under sandy soil conditions. M.Sc. Thesis, Zagazig Univ., Egypt.

Orozco, F.H., J. Cegarra, L.M. Trujillo and A. Roig (1996). Vermicomposting of coffee pulp using the earthworm Eisenia fetida: effects on $\mathrm{C}$ and $\mathrm{N}$ contents and the availability of nutrients. Biol Fertil Soils, 22:162-166.

Rajbir S., R.R. Sharma, K. Satyendra, R.K. Gupta and R.T. Patil (2008). Vermicompost substitution influences growth, physiological disorders, fruit yield and quality of strawberry (Fragaria $\times$ ananassa Duch.). Bioresour. Technol., 99: 8507-8511.

Shi-wei, Z. and H. Fu-zhen (1991). The nitrogen uptake efficiency from $15 \mathrm{~N}$ labeled chemical fertilizer in the presence of earthworm manure (cast). In: Veeresh GK, Rajagopal D, Viraktamath CA (eds) Advances in Management and Conservation of Soil Fauna. Oxford and IBH publishing Co, New Delhi, 539-542

Snedecor, G.W. and W.G. Cochran, (1980). Statistical Methods. $7^{\text {th }}$ Ed. Iowa State Univ., Press, Ame., Iowa, USA.

Tomati, U., A. Grapppelli and E. Galli (1988). The hormone-like effect of earthworm casts on plant growth. Biol. Fertil. Soils, 5: 288294.

Wallihan E.F., T.W. Embleton and P. Wilma (1958). Zinc deficiency in avocado. Califgric, 12 (6): 4-5.

Zende G.K. (1996). Integrated nutrient supply in relation to micronutrients for sustainable agriculture. Micronutrient News, 10 (11): 19. 
تأثير مصدر السماد العضوي والرش الورقى ببعض العناصر الصغرى على النمو و المحصول و جودة

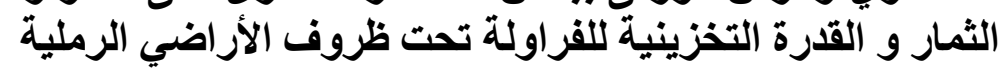

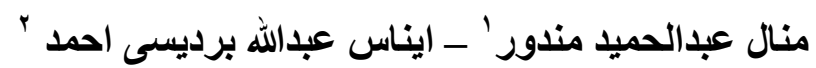

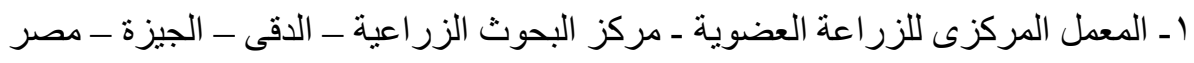

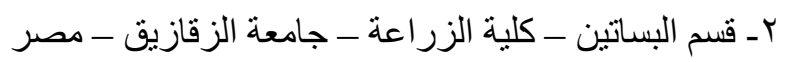

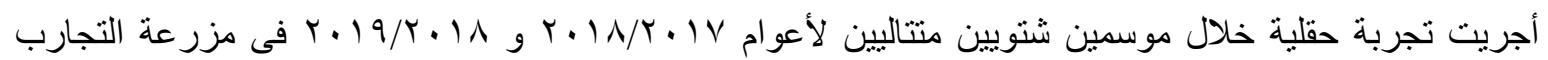

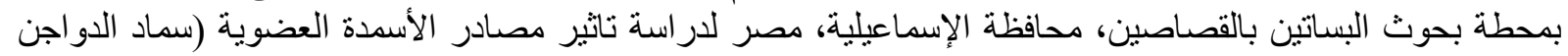

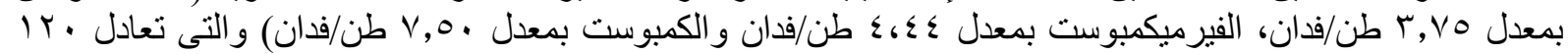

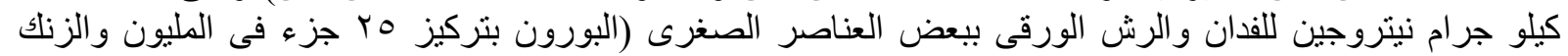

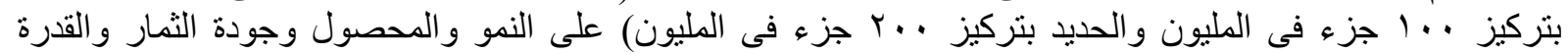

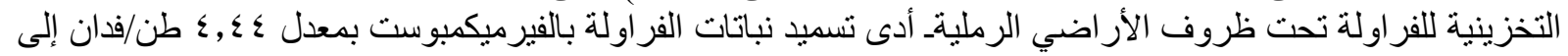

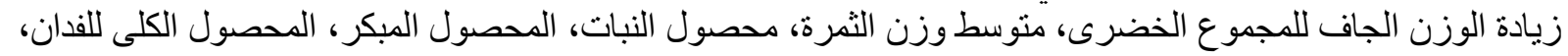

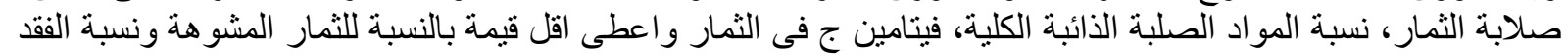

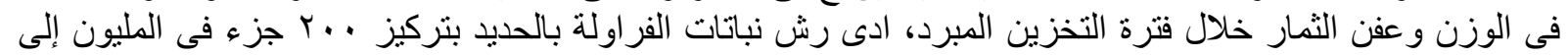

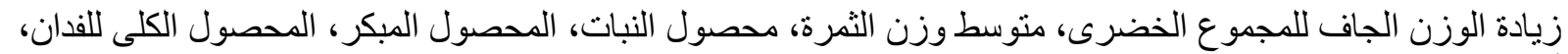

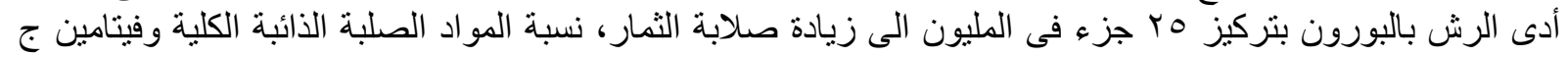

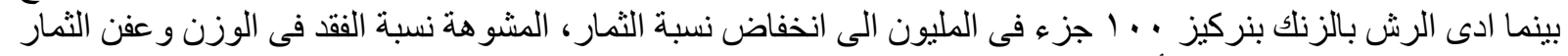

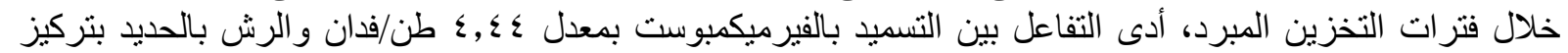

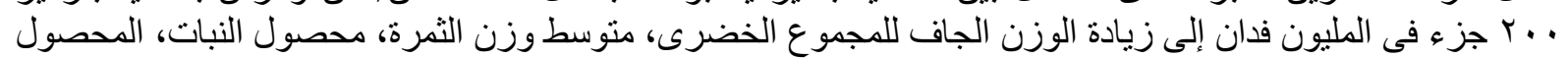

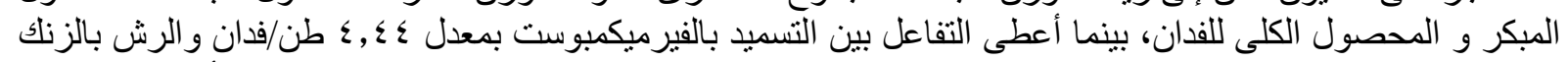

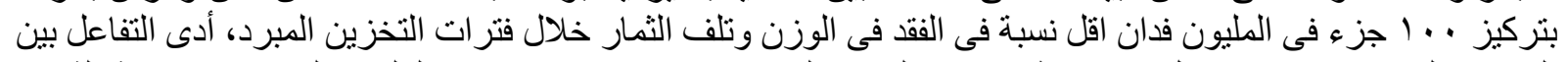

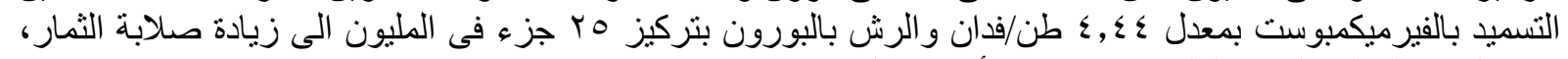

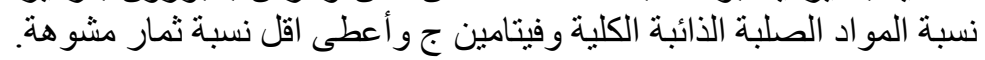

